\begin{tabular}{|c|c|}
\hline \multirow{3}{*}{ 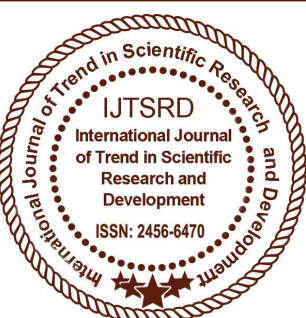 } & $\begin{array}{l}\text { International Journal of Trend in Scientific } \\
\text { Research and Development (IJTSRD) }\end{array}$ \\
\hline & International Open Access Journal \\
\hline & ISSN No: 2456 - 6470 | www.ijtsrd.com | Volume - 2 | Issue - 5 \\
\hline
\end{tabular}

\title{
Antibiogram of Bacterial Pathogens Associated with Urinary Tract Infections
}

\author{
Suvitha. T, Victoria. J \\ PG and Research Department of Microbiology, \\ STET Women's College Mannargudi, Thiruvarur, Tamil Nadu, India
}

\section{ABSTRACT}

The present study was carried out to isolate the bacterial species from the urine sample collected from 30 female patients with urinary tract infections and to test the antibiotic sensitivity pattern of the isolated bacteria. Samples were collected from the Government Hospital, Pattukkottai, Thanjavur District, Tamilnadu, India. The collected urine samples were streak plated different agar media. The bacterial colonies on the plates were subject to motility, gram staining and biochemical tests. E. coil, Klebsiella and Staphylococcus aureus were identified and confirmed using Bergey's manual of systematic bacteriology. Totally 29 isolates were obtained in which 18 were E. coli, 8 Klepsiella $\mathrm{Sp}$ and 3 Staphyococcus aureus species. Then the bacterial species were tested against the antibiotics such as Cefuroxime, Gentamicin, Nitrofurantion, Amaxicillium and Tetracycline. The antibiotic, gentamicin showed maximum activity against all the bacterial species followed by Cefuroxime, Nitrofurantioin, Amoxyullum and Tetracycline. Thus the present study reveals the importance of selecting a particular antibiotic for the treatment of urinary tract infections of female patients, those who are highly prone to the infection caused by the urinary tract infecting bacterial species. As drug resistance among bacterial pathogens is an evolving process, regular surveillance and monitoring is necessary to provide physician's knowledge on the updated and most effective empirical treatment of UTIs. Periodic reassessment of in vitro susceptibility pattern of ordinary pathogens to serve as a guide for antibiotic therapy since these organisms exhibit resistance to first - line drugs used for UTI infection.
Keywords: E.coli, Klepsiella Sp,Staphyococcus aureus Cefuroxime, Nitrofurantioin, Amoxyullum and Tetracycline, Urine.

\section{INTRODUCTION}

Urinary tract infection (UTI) remains the most common nosocomial infection in many hospitals and accounts for approximately $35 \%$ of all hospital acquired infections.

Sobia Rafique et al., (2002) studied UTI causes increased mortality in the critically ill patients and economic cost. The urinary tract is normally sterile, uncomplicated UTI involves the urinary bladder in a host without underlying renal or neurologic disease. The infection may occur at the genitourinary tract of urethra, bladder, ureter and kidney. UTI represents bladder (mucosal invasion in female appear particularly prone to colonization with colonic gram negative bacilli, which normally live in the colon and cause cystitis and pyelonephritis are common in women.

Urinary tract infections may involve just the lower tract or both the lower and upper tracts. Cystitis is the term used to describe infection of the bladder with signs and symptoms including dysuria, urgency and frequency. Pyelonephritis is the term used to describe upper tract infection, often with flank pain and tenderness and accompanying dysuria, urgency and frequency,

Acute inflections in non-catheteterized patients occur very commonly, especially in women between the ages of 20 and 50 and account for over 6 million 
office visits annually in the United States. In the vast majority of infection, bacteria gain access to the bladder via the urethra and move up the urinary tract to the kidneys. In women natal cluft is the root for the role causes UTI, because of the contacuity of rectum natal cluft and urethra. During menstrual period the urethral contamination also a predominant causes for more incidence of UTI. Since a women's urethra is shorter ( $4 \mathrm{~cm}$ long) than a man Women are more prone to UTI than man or children. The sexual intercourse may also promote this migration.

The prevalence and incidence of urinary tract infections are higher in women than in men. This is due to several clinical factors in women such as hormonal effects, behavior patterns or the presence of a short urethra and vaginal vesti-bule, which can be easily contaminated (Ebie et al., 2001; Kolawolea et al., 2009). Men who are un-curcimcised are more at risk to becomeinfected because the bacteria can build up much more easily in the folds of the extra skin of the penis as are men who engage in anal intercourse (Bhat et al., 2011).

\section{MATERIALS AND METHODS}

\section{SAMPLE COLLECTION}

Urine samples were collected from urinary tract infected female patients of age group 25-45 from Government Hospital, Pattukkottai, Thanjavur District, Tamil Nadu India. The urine samples were collected in a clean dry container examined and fresh, without delay. The first portion of urine flushes out commensal bacteria from the anterior urethra was discarded. The next portion of the urine (midstream sample) was collected directly in a sterile wide mouthed container and transported to the laboratory.
ANTIBIOTIC
SENSITIVITY
TEST
(Kirby Bauer, 1966)
The Muller Hinton Agar was prepared and sterilized at sterilized at $121^{\circ} \mathrm{C}$ for 15 minutes. After sterilization, the medium was poured into the different Petri Plates. And allowed for solidification. After solidification, different isolates were swabbed on the surface of the agar. Then, different antibiotic discs were placed and the plates were observed for the sensitivity and resistance of the particular isolate by measuring the diameter of the zone of inhibition in $\mathrm{mm}$.

\section{STATISTICAL ANALYSIS}

All the experiments were repeated as triplicates. The results obtained in the present study were subjected to statistical analysis like mean $\mathrm{X}$ and standard deviation (SD)

$$
\begin{aligned}
\mathrm{X} & =\left(\frac{\Sigma \overline{\mathrm{X}})}{\mathrm{N}}\right. \\
\text { mean }(\overline{\mathrm{x}}) & =\text { sum of all values of the variable } \\
(\mathrm{N}) & =\text { Number of observation }
\end{aligned}
$$

Where, add together all values of the variable $\mathrm{X}$, were added together and was divided the total by the number of observation. The standard deviation (SD) was calculated by the formula

$$
\begin{aligned}
& \text { (SD) } \sigma \sqrt{\frac{\Sigma(X-X) 2}{N}} \\
& \mathrm{X} \text { - Number of value }
\end{aligned}
$$

\begin{tabular}{|c|c|c|c|c|}
\hline $\begin{array}{l}\text { S.N } \\
0 .\end{array}$ & $\begin{array}{c}\text { Characteris } \\
\text { tics }\end{array}$ & $\begin{array}{l}\text { E.co } \\
\text { li }\end{array}$ & $\begin{array}{l}\text { Klebsie } \\
\text { lla sp }\end{array}$ & $\begin{array}{c}\text { Staphylococ } \\
\text { cus }\end{array}$ \\
\hline & \multicolumn{4}{|c|}{ Morphological characteristics } \\
\hline $\mathrm{S}^{1} \mathrm{ci}$ & $\begin{array}{c}\text { Gram } \\
\text { staining }\end{array}$ & 9 & $8-$ & - \\
\hline 2 & Motility & + & + & - \\
\hline 3 & Shape & Rod & Rod & Cocci \\
\hline \multicolumn{5}{|c|}{ Biochemical Characteristics } \\
\hline 4 & Indole & + & - & - \\
\hline 5 & MR & + & - & - \\
\hline 6 & $\mathrm{VP} \quad \mathrm{O}$ & - & + & + \\
\hline 7 & Citrate & - & + & - \\
\hline 8 & Urease & - & + & + \\
\hline 9 & TSI & - & - & - \\
\hline
\end{tabular}

Table 1

\section{RESULTS OF MORPHOLOGICAL AND BIOCHEMICAL TESTS FOR THE BACTERIAL ISOLATES}

\begin{tabular}{|c|c|c|c|c|c|c|}
\hline \multirow{5}{*}{$\begin{array}{l}\text { S. } \\
\mathbf{N} \\
\text { o. }\end{array}$} & \multirow{5}{*}{$\begin{array}{l}\text { Bacterial } \\
\text { Species }\end{array}$} & \multirow{5}{*}{$\begin{array}{l}\text { Total } \\
\text { No. } \\
\text { of } \\
\text { isolat } \\
\text { es }\end{array}$} & \multirow{5}{*}{$\begin{array}{l}\text { Percent } \\
\text { age }\end{array}$} & \multicolumn{3}{|c|}{ Age Group } \\
\hline & & & & 15 & 25 & 35 \\
\hline & & & & & & \\
\hline & & & & 25 & 35 & 45 \\
\hline & & & & \multicolumn{3}{|c|}{$\begin{array}{l}\text { No. } \\
\text { ofisolates }\end{array}$} \\
\hline 1. & E. coli & 18 & 62.07 & 5 & 6 & 7 \\
\hline 2. & $\begin{array}{c}\text { Klebsiella } \\
s p\end{array}$ & 8 & 27.58 & 2 & 3 & 3 \\
\hline 3. & $\begin{array}{l}\text { Staphylococ } \\
\text { cus aureus }\end{array}$ & 3 & 10.35 & 1 & 1 & 1 \\
\hline & Total & 29 & 100 & 8 & 10 & 11 \\
\hline
\end{tabular}

Table-2

DETAILS OF BACTERIAL SPECIES

ISOLATED FROM URINE SAMPLE (FEMALE) 
International Journal of Trend in Scientific Research and Development (IJTSRD) ISSN: 2456-6470

Table 3

\begin{tabular}{|c|c|c|c|c|c|}
\hline \multicolumn{6}{|c|}{$\begin{array}{c}\text { ANTIBIOTIC SENSITIVITY OF ISOLATED } \\
\text { BACTERIAL SPECIES }\end{array}$} \\
\hline \multirow{2}{*}{$\begin{array}{l}\text { Organ } \\
\text { isms }\end{array}$} & \multicolumn{5}{|c|}{ Sensitivity pattern } \\
\hline & $\begin{array}{c}\text { Cefu } \\
\text { roxi } \\
\text { me }\end{array}$ & $\begin{array}{l}\text { Gent } \\
\text { amici } \\
\text { n }\end{array}$ & $\begin{array}{l}\text { Nitro } \\
\text { furan } \\
\text { tion }\end{array}$ & $\begin{array}{l}\text { Ama } \\
\text { xicill } \\
\text { in }\end{array}$ & $\begin{array}{c}\text { Tetra } \\
\text { cyclin } \\
\text { e }\end{array}$ \\
\hline E. coli & $\mathrm{S}$ & $\mathrm{S}$ & $\mathrm{S}$ & $\mathrm{S}$ & $\mathrm{S}$ \\
\hline $\begin{array}{l}\text { Klebsi } \\
\text { ella } s p\end{array}$ & $\mathrm{~S}$ & $\mathrm{~S}$ & $\mathrm{~S}$ & $\mathrm{~S}$ & $\mathrm{R}$ \\
\hline $\begin{array}{c}\text { S.aure } \\
\text { us }\end{array}$ & $\mathrm{S}$ & $\mathrm{S}$ & $\mathrm{S}$ & I & $\mathrm{R}$ \\
\hline
\end{tabular}

S - Sensitive I - Intermediate

$\mathrm{R}$ - Resistant

Table 4

ANTIBIOTICS SUSCEPTIBILITY PATTERN OF ISOLATED BACTERIAL SPECIES

\begin{tabular}{|c|c|c|c|c|c|c|}
\hline \multirow[t]{2}{*}{$S$} & \multirow{2}{*}{$\begin{array}{l}\text { Organ } \\
\text { isms }\end{array}$} & \multicolumn{5}{|c|}{ Zone of inhibition (in $\mathrm{mm}$ ) } \\
\hline & & $\begin{array}{c}\text { Cefu } \\
\text { roxi } \\
\text { me }\end{array}$ & $\begin{array}{l}\text { Gent } \\
\text { amic } \\
\text { in }\end{array}$ & $\begin{array}{c}\text { Nitrof } \\
\text { uranti } \\
\text { on }\end{array}$ & $\begin{array}{l}\text { Amo } \\
\text { xicill } \\
\text { in }\end{array}$ & $\begin{array}{l}\text { Tetra } \\
\text { cycli } \\
\text { ne }\end{array}$ \\
\hline 1 & E. coli & $\begin{array}{c}19.05 \\
\pm \\
1.74 \\
\end{array}$ & $\begin{array}{c}14.04 \\
\pm \\
1.26 \\
\end{array}$ & $\begin{array}{c}12.05 \\
\pm \\
1.18\end{array}$ & $\begin{array}{c}11.0 \\
1+ \\
1.10 \\
\end{array}$ & $\begin{array}{c}10.00 \\
\pm \\
1.0 \\
\end{array}$ \\
\hline 2 & $\begin{array}{l}\text { Klebsi } \\
\text { ella sp }\end{array}$ & $\begin{array}{c}16.02 \\
\pm \\
1.37 \\
\end{array}$ & $\begin{array}{c}11.02 \\
\pm \\
1.2\end{array}$ & $\begin{array}{c}09.02 \\
\pm \\
1.0\end{array}$ & $\begin{array}{c}07.0 \\
0 \pm \\
0.88 \\
\end{array}$ & $\begin{array}{c}08.08 \\
\pm \\
0.95 \\
\end{array}$ \\
\hline 3 & $\begin{array}{c}\text { Staphy } \\
\text { lococc } \\
\text { us } \\
\text { aureus }\end{array}$ & $\begin{array}{c}06.05 \\
+ \\
0.85\end{array}$ & $\begin{array}{c}08.00 \\
\pm \\
0.92\end{array}$ & $\begin{array}{c}09.01 \\
\pm \\
1.0\end{array}$ & $\begin{array}{c}06.0 \\
3 \pm \\
0.84\end{array}$ & $\begin{array}{l}05.01 \\
\pm \pm(e \\
1.33\end{array}$ \\
\hline
\end{tabular}

Values are triplicates represented as Mean \pm Standard Deviation.

\section{DISCUSSION}

Microbial invasion of the kidneys, ureters, bladder and urethra is known as Urinary Tract Infection (UTI) (Beer et al., 2006). This may be characterized by an inflammation of the urothelium (Andersson, 2004) and the infecting pathogens affecting the entire urinary tract, or be restricted to either the upper region or lower region (Stamm and Norrby, 2001). The bacterial that cause UTI are primarily of the Gram negative group with prevalence of eighty to eightyfive percent. The most frequently reported members of these bacteria are E.coli and Klebsiella (Eghafona et al., 1998; Ebie et al., 2001; Omonigho et al., 2001). However, in complicated UTI, the prevalence of other antibiotic resistance organisms such as Proteus, Serratia, Enterobacter and Pseudononas increases. The prevalence and degree of occurrence of one or two of these organisms over others are dependent on the environment (Omonigho et al., 2001). This is because they easily gain access to the urethral opening due to proximity to the anus and they constitute a serious problem in UTI in many parts of the world (Naeem, 2001).

The bacterial isolates were seeded into the MuellerHinton agar medium using a sterile cotton swab dipped into the standardized suspension, drained, and used for inoculating the medium. Inoculated plates were allowed to stand for about 10 minutes before sterile forceps were used to aseptically transfer some antibiotic sensitivity disks onto the surface of the cultured plates. The Plates were incubated aerobically at $37^{\circ} \mathrm{C}$ for $18-24$ hours. After incubation, the diameters of the zones of inhibition were observed and measured (Zinnah, 2008) with a ruler and compared with a zone-interpretation chart (Bauer et al., 1966).

The management of urinary tract infection is an issue that needs to be addressed urgently. Effective management can be instituted through proper identification of the etiological agents and administration of the appropriate antimicrobial agents (Kebira et al., 2009).

The prevalence of UTI infection is higher in females than in males. Of the 74 isolates obtained, 65 were from female patients while 9 were from males. This is in agreement with other reports, which stress that UTI is more frequent in females than in males, during youth and childhood because of differences in anatomical structure, sexual maturation and the changes that occur during pregnancy and child-birth as well as the presence of tumors (Asinobi et al., 2003: Olaitan 2006; Mbata, 2007).

Majority of the bacteria isolated in this study were Gram positive and this is in accordance with the results obtained in other studies (Laupland et al., 2007; Mbata 2007). But unlike the findings of other researchers who reported E.coli to be the predominant pathogen associated with UTI (Obiogbolu et al., 2009; Hamdan et al., 2011; Oladeinde et al., 2011; Olurei et al., 2011) a high prevalent rate of 40.54 percent was recorded for Klebsiella $s p$ in this study.

\section{CONCLUSION}

The present study was carried out to isolate the bacterial species from the urine sample collected from 30 female patients with urinary tract infections and to 
test the antibiotic sensitivity pattern of the isolated bacteria. Samples were collected from the Government Hospital, Pattukkottai, Thanjavur District, Tamilnadu, India. The collected urine samples were streak plated different agar media. The bacterial colonies on the plates were subject to motility, gram staining and biochemical tests. E. coil, Klebsiella and Staphylococcusaureus were identified and confirmed using Bergey's manual of systematic bacteriology. Totally 29 isolates were obtained in which 18 were E. coli , 8 Klepsiella $S p$ and 3 Staphyococcus aureus species. Then the bacterial species were tested against the antibiotics such as Cefuroxime, Gentamicin, Nitrofurantion, Amaxicillium and Tetracycline. The antibiotic, gentamicin showed maximum activity against all the bacterial species followed by Cefuroxime, Nitrofurantioin, Amoxyullum and Tetracycline. Thus the present study reveals the importance of selecting a particular antibiotic for the treatment of urinary tract infections of female patients, those who are highly prone to the infection caused by the urinary tract infecting bacterial species. As drug resistance among bacterial pathogens is an evolving process, regular surveillance and monitoring is necessary to provide physician's knowledge on the updated and most effective empirical treatment of UTIs. Periodic reassessment of in vitro susceptibility pattern of ordinary pathogens to serve as a guide for antibiotic therapy since these organisms exhibit resistance to first - line drugs used for UTI infection. In order to prevent or decrease resistance to antibiotics, the use of antibiotics should be kept under supervision, should be given in appropriate doses for an appropriate period of time.

\section{REFERENCES}

1. Kolawale A S, Kandaki oy, Balatunde S k, Durowade K A, Kolawole C F, 2009. Prevalence of urinary tract infection among patients attending dalhatu Araf specialist Hospital, Latia, Nasarawa State, Nigeria, Int j Med Sci, 1(15): 163 - 167

2. Kebira A N, Ochola P, Khamadi S A, 2009. Isolation and antimicrobial susceptibility testing of Escherichia coli causing urinary tract infections, appl Biisci 22: 1320 - 1325.

3. Naccm .A, 2010 urinary tract bacterial pathogens: Their antimicrobial susceptibility patterns Profs 7(2): $131-132$.

4. Bashir M F., Qazi, j I A h Med., N., and Riaz, 2008. Diversity of orinary tract pathogens and drug resistant Isolates of Escherichia Coli in different age and gender groups of Pakistanis. Tropical J. Pharma Research 7(3): 1025 - 1031.

5. Okeke In, Lamikanra A, Edelman .R, 1999 Socio Economic and behavioral factors leading to acquired bacterial resistance to antibiotics in developing countries emerg Infect Dis, 5 (1): 18 27

6. Piper, K. 2002.soil sampling and method of analysis Canadian society of soil science, Lewis pub., Boca Raton.

7. Stotzky, G., 1997, Soil as an environment for microbial life .Modern Soil Microbiology. Academic Press. New York.

8. Warcup, J. H. 1950. The soil plate methods for fungi from soil. Nature 117-118.

9. Waxman, S. A. 1922. Dilution Plate Technique. J. Bacteriol., 1 139-140.

10. Williams, C. M and Richter, C. S. 1990. Isolation, identification and characterization of a feather degrading bacterium. Applied and Environmental Microbioplogy, 56: 1509-1515.

11. Aneja, K. R. 2002. Experiment in microbiology, plant pathology, tissue culture and mushroom production technology. $4^{\text {th }}$ ed New Age International (p) Ltd, New Delhi. 162-163.

12. Beijerinck, Bergey's Manual of Systematic Bacteriology. 8th ed. 1889, Baltimore: Williams and Wilkins Co., in press.

13. Baumann, P. M, Gauthier and Baumann. I, Genus Alteromonas.in: krieg, N. R.(ed), Bergey's Maual of Systematic Bacteriology.1983, 9th ed. Baltimore: Williams and Wilkins Co., in press 